\title{
REDUCING THE BARRIERS TO INTERNATIONAL TRADE IN ACCOUNTING SERVICES: WHY IT MATTERS, AND THE \\ ROAD AHEAD
}

Lawrence J. White

Stern School of Business

New York University

\author{
Presented at \\ the conference on \\ "Services 2000: New Directions in \\ Services Trade Liberalization" \\ Washington, DC \\ June 1-2, 1999; \\ and at the \\ American Enterprise Institute \\ Washington, DC \\ October 5, 1999
}

Draft: $5 / 3 / 00$

Comments welcomed.

\begin{abstract}
$\underline{\text { Abstract }}$
Accounting has been a lead sector in the General Agreement on Trade in Services (GATS) negotiations to reduce barriers to trade in professional services. This is no accident. Accounting already has a substantial international component; the largest accounting firms have major international presences and have been eager to operate in less restrictive environments. Accounting is coming to be understood as a vital infrastructural element of financial services, and as finance becomes more global, accounting too should become more global. Similarly, as large businesses enterprises generally have become more international, their need for more international accounting services has grown. But, despite the considerable international presences of the major accounting firms, virtually all countries maintain various types of restrictions that impede the flow of accounting services across borders. The consequences have been higher costs, poorer service to clients, and reduced efficiency, as well as lower quality accounting/auditing standards in many countries. Substantial progress can and should be made to reduce the current barriers to freer trade in accounting services.
\end{abstract}




\title{
REDUCING THE BARRIERS TO INTERNATIONAL TRADE IN ACCOUNTING SERVICES: WHY IT MATTERS, AND THE \\ ROAD AHEAD
}

\author{
Lawrence J. White* \\ Stern School of Business \\ New York University
}

(Draft: 5/3/00)

\section{Introduction}

Accountants and accounting are essential -- though often undervalued -- elements of the infrastructure of any enterprise. Information about a firm's financial accounts is vital for managers, owners, and creditors; it is a key input for lenders' and investors' decisions as to whether, when, and how to provide finance to enterprises. ${ }^{1}$ Accounting is thus an important part of the business sector of any modern economy.

The growth of multinational enterprises generally and of multinational accounting firms in particular has focused attention on issues related to international trade in accounting services. This attention, in turn, is part of a rising tide of interest in trade in a wide range of services.

The street-level disruptions at the Seattle Ministerial Conference of the World Trade Organization in November-December 1999 were an unfortunate slowing of the general process of

\footnotetext{
* Thanks are due to Claude Barfield, Charles Heeter, John Hegerty, Harry Freeman, and Vincent Sacchetti for valuable comments on earlier drafts.

${ }^{1}$ For discussions of the role of information, including accounting information, in the processes of finance, see White (1998) and Goldberg and White (2001).
} 
liberalizing international trade in goods and services. Given the momentum of over five decades of international progress in reducing the barriers to trade in goods and the recent substantial interest in liberalizing trade in services, however, it seems likely that the Seattle events will represent only a brief stumble on the path to freer international trade.

Prior to the Ministerial Conference, substantial progress had been made with respect to establishing international commitments for freer trade in accounting services, and the continuation of this progress seems likely.

The reasons for this progress, and why it matters, will be the major focus for this paper. Section II will briefly provide background on the nature of the progress that has been made. In Section III we will review why trade in services is different from trade in goods but also why the economic gains from wider trade are just as important for services as they have been for goods. Section IV will describe the essential features of modern accounting services and the modern accounting industry. Section V will focus on the impediments to the efficient flows of accounting services across borders. Section VI will explore the issues surrounding a related topic: the question of whether the differing accounting standards or frameworks that are used in different countries constitute a serious impediment for accounting services and whether harmonization of these standards is the right approach. Section VII will review the framework in which trade-in-services negotiations take place and the specific advances in that framework that have been achieved for accountancy. Section VIII then discusses the road ahead for negotiations specifically with respect to accounting services. And Section IX provides a brief conclusion. 


\section{Background}

Beginning in the late 1970 s there was a growing realization that trade in services should be the next major area for reductions in barriers. Since the end of the Second World War substantial progress had been made in reducing barriers to trade in goods through a succession of multilateral negotiating "rounds" under the auspices of the General Agreement on Tariffs and Trade (GATT). Though international trade in goods was hardly free of all protectionist restraints and considerably more progress could (and would) be made, trade in services had been largely untouched.

Trade in services became a major topic of discussion during the so-called Uruguay Round of GATT negotiations of the late 1980s. Those negotiations ultimately led to the creation of the World Trade Organization (WTO), as the successor to the GATT, and to a General Agreement on Trade in Services (GATS), which has served as the vehicle for the specific negotiations concerning reductions in the barriers to international trade in services.

Included in these negotiations has been a major initiative focusing on professional services. The WTO Working Party on Professional Services (WPPS), ${ }^{2}$ which came into existence in 1995 , selected accounting as the first of the professional services areas for the development of a set of multilateral "disciplines": rules that limit the protectionist nature of the domestic regulatory requirements that typically apply to accountants and accounting. These multilateral disciplines were adopted by the WTO's Council on Trade in Services in December 1998 and will serve as the

\footnotetext{
${ }^{2}$ The WPPS has since been transformed into the Working Party on Domestic Regulation.
} 
bases for reductions in international restrictions at the conclusion of future negotiations. ${ }^{3}$ Earlier (in 1997) the WPPS completed the development of guidelines for the negotiation of mutual recognition agreements (MRAs) that would apply to professional qualifications of accountants in various countries. These guidelines were adopted by the Council in May 1997.

The choice of accounting as a lead sector for reducing barriers was not accidental. Accounting already has a substantial international component; the largest accounting firms have major international presences and have been eager to operate in less restrictive environments. Accounting is coming to be understood as a vital infrastructural element of financial services, and as finance becomes more global, accounting too should become more global. Similarly, as large businesses enterprises generally have become more international, their need for more international accounting services has grown.

Despite the considerable international presences of the major accounting firms, however, virtually all countries maintain various types of restrictions that impede the flow of accounting services across borders. The broad provisions of the GATS and the multilateral accounting disciplines that were adopted by the WTO in 1998 will apply only after further negotiations are completed; in the interim WTO members are committed to a "standstill" arrangement: They will forbear from imposing heightened trade barriers to trade in accounting services. ${ }^{4}$

The substantial barriers that are currently in place provide prime targets for efforts to reduce

\footnotetext{
${ }^{3}$ For a general discussion of the adoption of these disciplines, see Ascher (1999).

${ }^{4}$ It was the absence of here-and-now progress, as well as concerns about the weakness of the disciplines, that caused the International Federation of Accountants (IFAC) to express tepid support for the disciplines; see IFAC (1998).
} 
and remove restrictions. Even in the wake of the Seattle experience, substantial progress can and should be made. 


\section{Why International Trade In Services Is (and Isn't) Different from Trade in Goods}

In many respects international trade in services is importantly different from trade in goods. Indeed, the fact that multilateral negotiations on trade in services began in earnest four decades after the beginning of multilateral negotiations on trade in goods is a testament to this difference.

On the other hand, there is at least one important way in which trade in services is not different: in providing the potential for improving a country's allocation of resources and thus raising its overall standard of living.

This Section will first explore this latter notion, in order to motivate the general discussion in this paper of the importance of reducing the barriers to international trade in accounting services. We will then turn to the important ways that services are different.

\section{A. Trade in services isn't different: improving efficiency.}

The basic economics argument for reducing or eliminating impediments to trade rests on the improvements in efficiency in the allocation of a country's resources that result from such actions. ${ }^{5}$ In essence, trade allows a country to focus its resources and energies on what it does relatively better than the rest of the world, importing those things that it does less well and paying for its imports by exporting the things that it does especially well. Though there are legitimate theoretical exceptions that can be offered to the free trade argument, the fundamental case for free trade is a

\footnotetext{
${ }^{5}$ The case for free trade can be found in any international economics text; see, for example, Yarbrough and Yarbrough (1997).
} 
powerful one, and it has now been buttressed by decades of empirical evidence indicating that reduced barriers to trade generally have had the beneficial effects that have been promised.

Though the case for free trade is almost always couched in terms of flows of goods, the same principles apply equally validly to trade in services. If a country is relatively less efficient at producing a set of services than are some other countries, then the first country will generally be better off by allowing the others to supply those services and instead focusing its resources on the goods and services in which it is relatively more efficient.

At its heart, the case for the beneficial consequences from free (or freer) trade is just the case for competitive markets, expanded to an international context. The case for competitive markets applies equally validly to services as to goods; so does the case for free trade.

\section{B. The ways in which trade in services is different.}

Understanding international trade in goods is relatively straightforward: Goods can be seen. They move physically across borders. Their movement is easy to visualize, as are many of the impediments to their movement: tariffs, quotas, and even more subtle impediments, such as customs delays at borders, regulatory procedures that favor national producers over foreign producers, etc.

By contrast, trade in services is different, in at least two important ways. First, services are usually intangible. They can't be seen, held, touched, or smelled. They usually don't physically cross borders the way that goods do. Second, services are often extensively regulated by governments -- more often than is true for goods. Appreciating both differences is useful for understanding why liberalization negotiations have been slower for services than for trade. 
1. Services are intangible. Because services are invisible (indeed, international services remittances are sometimes described as part of "invisibles" in discussions of a country's balance of payments), they are not delivered in the same way as is true for goods. The four following methods of delivery are listed in Article I of the GATS and are frequently described as the four modes of supply under the GATS:

a. Cross-border. Some services do actually cross borders. This is true for electricity and electronic information and also for some financial services (e.g., a bank that has its offices in country A may grant a loan to or accept a deposit from a customer that is located in country B). But these services do not stop and wait at a port of entry, while a customs official inspects and categorizes them and levies a duty. Instead they move instantaneously and invisibly.

b. Consumption abroad. Some services involve the travel of the customer from Country B to the location of the enterprise that offers the services in country A. Tourism is a common example.

c. Commercial presence. Some services may best be delivered through the establishment of a physical presence at one or more specific locations. For example, a bank that is headquartered in Country A may prefer to establish a branch location in Country B in order to do business with customers in the latter country. Many long-term service relationships are best developed and enhanced through the local presence of physical establishments.

d. Temporary presence (presence of natural persons). Some services may be provided on a temporary basis, through the nationals of Country A visiting Country B to deliver the services. Entertainment services (e.g., concerts by visiting orchestras or rock stars), short-term consultancies, or construction services can be delivered in this fashion. 
Some services may be capable of being delivered through more than one of these methods and/or through a combination of them.

The commercial presence method is common in services. But this commercial presence means that the delivery of the service in country B will require a services firm that is headquartered in Country A to make investments in Country B in order to establish that location. And also personnel from the service deliverer's headquarters will have to make on-site visits to the branch location in Country B: to deliver services, to hire local personnel, to supervise those personnel, etc. This need for investment and staffing that must originate from Country A in order to deliver services in Country B clearly makes the process of delivering services across borders more complicated than is true for the simple shipment of goods, and it provides greater and more subtle opportunities for governments to impede the flow of services. Restrictions on inbound foreign investment (including ownership structures and arrangements), on immigration, and on commercial location and establishment will all serve to restrict the inflow of imported services.

The delivery of accounting services is highly dependent on the physical presence of local establishments (i.e., the "commercial presence" method). In addition, the larger accountancy firms (see Section IV) make liberal use of short-term consultancies (i.e., the "temporary presence" method) in their efforts to mobilize specific sources of expertise within their firms. Whether the continuing technological revolution in telecommunications and data processing will allow accountancy to be less dependent on these methods and instead to be able to provide more of their services from afar -- i.e., the "cross-border" method -- remains an open question.

As will be discussed in Section V, given the current methods of delivering accounting services, the types of restrictions discussed above are indeed important impediments to the freer 
flow of accounting services.

2. Regulation. Services are more prone to various forms of governmental regulation or outright government ownership. As of the 1970s, the typical list of industries in the U.S. that were described as "heavily regulated" (or, outside of the U.S., were either regulated or in the hands of governments) included transportation services (air, rail, road, water), telecommunications services (broadcasting, telephony), financial services (banking, insurance, securities), and electricity. ${ }^{6}$ It was this same list of industries that became the prime targets for the deregulation efforts of the late 1970s and the 1980s in the U.S. (and for deregulation/privatization efforts in other countries). Despite the substantial deregulation that has occurred, however, these sectors continue to be more regulated than most other areas of the U.S. economy. ${ }^{7}$

In addition, professional services (e.g., medical, legal, accounting, architecture, engineering) have been subject to extensive direct and indirect governmental regulation. The direct form of regulation occurs through the actions of formal government agencies. The indirect form occurs when governments delegate to professional organizations many of the regulatory roles that would otherwise be exercised by government; but even with such delegations the ultimate regulatory powers are still held by governments.

The reasons for the extensive government involvement in the delivery of these services are

\footnotetext{
${ }^{6}$ Also, the natural gas industry was heavily regulated, and the price regulation of petroleum that began during the general wage and price controls of the early 1970s persisted through the late 1970s.

${ }^{7}$ For example, the U.S. airline industry was substantially deregulated between 1978 and 1984. Nevertheless, there remains today a ceiling of $25 \%$ foreign ownership that applies to any airline that serves domestic routes. Effectively, foreign ownership of domestic U.S. airlines is not permitted. Similar restrictions apply to ocean shipping; see White (1988) and Fox and White (1995).
} 
varied, but consumer protection is a common theme. ${ }^{8}$ In turn, consumer protection may be couched either in terms of protection against the exercise of monopoly power or in terms of protection against the abuses that could arise because of the complicated nature of the services and the superior knowledge of the services provider vis-a-vis the customer. ${ }^{9}$ But it is an easy jump from regulation that is supposed to protect consumers to regulation that is "captured" by the regulated entities; in the latter case, regulation may well harm consumers by protecting the incumbent services providers from the rigors of competition. ${ }^{10}$

This extensive overlay of regulation of many services thus adds important extra elements to any efforts to liberalize international trade in these services. First, the regulation is present, and, arguably, it is there for a reason. Efforts to liberalize trade have to confront the question as to whether trade in services is compatible with the protections that the regulation is supposed to be providing. Next, there are extra procedures, extra laws, extra agencies that must be dealt with. And there are the incumbent firms that can wrap themselves in the mantle of consumer protection and argue to home-country government officials that this protection will be weakened if providers from abroad are allowed under the tent.

As will be discussed in Section V, these patterns of professional-services regulation apply squarely to accounting.

In sum, services are different. Their mode of delivery and their tendency to be regulated

\footnotetext{
${ }^{8}$ See, for example, Mills and Young (1999).

${ }^{9}$ In more formal economics terms, this latter problem is frequently described as the problem of asymmetric information.

${ }^{10}$ See, for example, Stigler (1971), Posner (1974), and Peltzman (1976).
} 
have created delays and extra barriers to the opening of trade in services. Indeed, the structure of the GATS recognizes these differences, setting less ambitious goals for the dismantling of barriers in the services areas than is true for goods. Nevertheless, the GATS represents a substantial effort toward freer trade in services, and accounting services are an important part of that effort. It is to a deeper exploration of accounting services that we now turn. 


\section{Accounting Services in International Trade: A Snapshot}

\section{A. Accounting services. ${ }^{11}$}

The scope of "accounting services" is usually understood to include accounting/bookkeeping (measuring and recording the financial flows and positions of an enterprise), auditing (verifying and attesting/certifying the accuracy of the financial position and results of the enterprise, for internal or external purposes), and tax preparation. The three activities are clearly closely related.

In addition, over the past few decades the largest accounting firms -- especially in the U.S. - have become actively involved in management consulting, and growth in this area has been considerably more rapid than for the firms' more traditional services. As can be seen in Table 1, as of 1998 management consulting contributed almost half (47\%) of the domestic revenues of the 100 largest U.S. accounting firms, with accounting/auditing/tax services contributing the remainder $(53 \%)$. For the largest of the large -- the Big Five ${ }^{12}$ firms -- the corresponding percentages were $51 \%$ and $49 \%$, respectively. For the Big Five, their defining services are no longer their dominant sources of revenues! $!^{13}$ Between 1997 and 1998 management consulting revenues grew by $38 \%$ for both the largest 100 and the Big Five.

${ }^{11}$ See, generally, Weinstein (1987) and Most (1993).

12 These firms are PricewaterhouseCoopers, Arthur Andersen, Ernst \& Young, KPMG Peat Marwick, and Deloitte \& Touche.

${ }^{13}$ By contrast, as the mid 1980s, accounting/auditing was responsible for well over half of the revenues of the large accounting firms, and tax services and management consulting were each responsible for well under a third; see Rossi (1986). 
Management consulting has been a natural, synergistically related service for the large accounting firms. Through the provision of their traditional accounting/auditing/tax services, they acquire a considerable amount of detailed information about an enterprise's operations, which they then use, enhanced with additional expertise, to help the enterprise develop and achieve its tactical and strategic goals. One of the latest facets of management consulting by accounting firms -information systems consulting -- is again a synergistic use of their expertise as information handlers and users.

The auditing function of these firms has gained special significance in the past few decades with the rise in importance of publicly traded companies and the securities markets. Investors in and lenders to publicly traded enterprises rely heavily on those enterprises' audited financial statements as an accurate statement of the enterprise's financial position and results. Bond covenants and banks' lending agreements often contain restrictions couched in terms of the financial flows and positions of the borrowing enterprise, measured according to generally accepted accounting principles (GAAP) and certified through an audited financial statement. Indeed, the certification value of the Big Five accounting firms has become so great that virtually all of the "Fortune 500" U.S.-based companies are audited by the Big Five, and a high fraction of the next 500 are also audited by the Big Five. If the largest three ${ }^{14}$ of the next tier of accounting firms are included, the coverage of the "Fortune 1000 " is virtually complete. ${ }^{15}$ Similarly, when young

${ }^{14}$ Grant Thornton, BDO Seidman, and McGladrey \& Pullen.

15 A study of the auditors of the largest publicly traded non-financial companies, as of 1995 , found that the Big Six (now Big Five) audited all 241 of the companies with assets over $\$ 5$ billion, 548 of the 551 companies with assets between $\$ 1$ billion and $\$ 5$ billion, and 363 of the 372 companies with assets between $\$ 0.5$ billion and \$1.0 billion; see Doogar and Easley (1995). 
companies first issue securities through initial public offerings (IPOs), the investment bankers/underwriters that shepherd the new issues into the securities markets almost always insist on the certifying value of one of these eight or so largest accounting firms.

As another indication of the dominance of the Big Five firms, in 1999 the 100 largest accounting firms in the U.S. had aggregate revenues of about \$31 billion (including management consulting revenues); the Big Five constituted $89.9 \%$ of this total. ${ }^{16}$

\section{B. The international dimension.}

Despite the limitations and restrictions on their international activities that will be discussed in the next Section, the largest accounting firms have all developed substantial international presences. Much of this spread of international presence has occurred as a consequence of the international growth of their clients and the desire of the individual clients to retain their accounting firms across international boundaries. The expertise and prestige of the largest accounting firms have also allowed them to acquire overseas clients that have no roots in the accounting firms' home countries and/or to affiliate with local accounting firms, forming networks and partnerships under a common brand name.

The overall effects have been striking. Though four of the Big Five accounting firms are headquartered in the U.S. (and though the fifth, KPMG, is headquartered in Amsterdam it has a strong U.S. presence and orientation), the Big Five now derive approximately $65 \%$ of their

\footnotetext{
${ }^{16}$ See Accountancy International, Vol. 124, October 1999, p. 8.
} 
revenues from locations outside of the U.S. ${ }^{17}$ Table 2 lists the numbers of countries in which the largest twenty accounting firms/networks have locations. The Big Five tend to be in the most locations, but even the smaller networks can be found in dozens of countries.

Further, the Big Five are by far the largest accounting firms in the world, as is indicated in Table 3. As can be seen, the Big Five together account for $77 \%$ of the revenues of the 40 largest international accounting networks, and there is a sharp drop between the sizes of the fifth firm (Deloitte) and the sixth (BDO). Further, of the 100 largest firms worldwide (as measured by market value at the end of 1999), the Big Five audited 98 of them. ${ }^{18}$

It is also worth noting that, of the dozen largest accounting firms worldwide, nine are headquartered in the U.S., two are headquartered in the U.K., and one is headquartered in the Netherlands. These dozen largest firms thus have a strong North American/Western European orientation. This worldwide dominance by trans-Atlantic oriented firms is partly explained by the worldwide presence of large North American and Western European-headquartered corporations generally (and the desire of these corporations to retain their domestic accounting firms as they expand abroad) and partly by the large base that these trans-Atlantic economies have provided and the greater relative importance that these countries' economies, securities markets, and securities laws (especially in the U.S. and the U.K.) have placed on accounting and auditing.

The international presences by these large accounting firms have special features. As Tables 2 and 3 indicate, these international accounting firms are often described as "networks." The

17 This estimate is derived from the data found in the tables compiled by Accountancy International, Vol. 124, August 1999, p. 8 and October 1999, p.8.

${ }^{18}$ See Accountancy International, Vol. 125 (April 2000), p. 12. 
firms themselves are always partnerships, and their affiliations and alliances across international borders are fluid and varied; indeed, in the international context, the characterization of the large firms as "partnerships of partnerships" is quite apt. ${ }^{19}$ The annual data compilation in Accountancy International, from which the data for Tables 2 and 3 were drawn, has a separate column for the number of "member firms" that comprise each of the major networks. Ernst \& Young, for example, lists 123 member firms; KPMG lists 146.

These fluid and varying arrangements with respect to local affiliates are often adaptations and accommodations to the local limitations imposed by national governments (to be discussed in the next Section). Nevertheless, despite these limitations, the "brand name" of each of the large firms -- especially the Big Five -- is important, and their international presences are substantial.

Another aspect of the international presence and dominance by the large U.S.-headquartered (or U.S.-oriented) accounting firms is their consequences for the U.S. balance of payments. In 1998 U.S. direct exports of "accounting, auditing, and bookkeeping services" plus "management, consulting, and public relations services" totaled $\$ 2.0$ billion, while imports of the same categories of services totaled $\$ 1.2$ billion, yielding a net export surplus of $\$ 0.8$ billion. ${ }^{20}$ In 1996 the sales of "accounting, research, management and related services" by overseas affiliates of U.S. firms to foreign purchasers totaled $\$ 7.7$ billion, while the U.S. affiliates of foreign companies sold $\$ 2.0$

\footnotetext{
${ }^{19}$ See, for example, Aharoni (1993).
}

${ }^{20}$ See Mann et al. (1999). These export and import flows include intra-firm transactions that crossed borders. The "management, consulting, and public relations services" category includes companies that are not accounting firms. It is also worth noting that for "accounting, auditing, and bookkeeping services" alone, the U.S. had a small net export surplus in 1998 of \$15 million; larger net export surpluses were experienced in the early 1990s. 
billion of the same category of services to U.S. purchasers; ${ }^{21}$ thus the net flow of sales was a positive $\$ 5.7$ billion by U.S. firms.

Despite these substantial international presences and magnitudes of transactions by the large accounting firms, the extensive local regulation of accounting services makes these international operations more difficult and costly than would otherwise be the case. It is to these impediments that we now turn.

\footnotetext{
${ }^{21}$ See Mann et al. (1999); comparable figures are not available for later years.
} 


\section{$\underline{\text { V. The Impediments to Trade in Accounting Services }}$}

As a professional service (like medicine, law, architecture, engineering, etc.), accounting has been subject to substantial domestic regulation in virtually all countries. ${ }^{22}$ Though the detailed requirements vary from country to country, accountants typically must satisfy education and practical experience requirements and must satisfy a local residency requirement, and often must pass a qualifying/licensing exam. The organizational form/structure of accounting firms is typically restricted as well. Accounting firms are often limited to partnerships or sole proprietorships; corporate forms are often prohibited. And ownership of accounting firms is often limited to accounting professionals.

Further, the forms and procedures involved in the service itself -- e.g., accounting standards and auditing procedures -- are usually regulated. Sometimes, advertising or other forms of promotion and price competition are restricted or prohibited.

Regulation usually occurs at the national level, but in some countries -- notably, the U.S., Canada, and Australia -- regulation has devolved to the state or province level and varies among jurisdictions. ${ }^{23}$ Regulation may be carried out by formal governmental agencies or be delegated to

${ }^{22}$ Summaries and reviews of these requirements can be found in $\operatorname{OECD}(1996,1997)$ and WTO (1998). Management consulting is generally not considered to be a profession in the same sense as accounting (or law, medicine, etc.) and is generally less highly regulated, but some of the restrictions discussed later in this Section (e.g., restrictions on the mobility of personnel, restrictions on payments, inadequate protection for intellectual property, "buy national" policies by governments) apply to management consulting as well.

${ }^{23}$ For a summary of the variations in accounting regulations across the 50 United States, see AICPA/NASBA (1998). 
professional organizations or be combined in a mixture of the two.

The surface goal of such restrictions is consumer protection: to ensure that only qualified individuals provide the service, that the integrity and quality (independence, objectivity) of the service and the service provider are maintained, that conflicts of interest are minimized, and that aggrieved consumers have the opportunity for obtaining redress.

The goal of consumer protection can be readily subverted, however. These types of restrictions are barriers to entry. If enforced perfectly, the restrictions would exclude only the charlatans and quacks. But incumbent providers will always realize that the restrictions -- perhaps, with some supplements -- can also be used to exclude competitors more broadly. Further, as technologies change and improve and as customer competence and capabilities improve, regulatory restrictions that might have been necessary or at worst harmless in one era may become inappropriate and seriously distortionary in a later era. But the forces of inertia, buttressed by the vested interests of protected incumbents, are more powerful when regulatory institutions and procedures are in place.

This appears to be the case for accounting services. As was documented in Section IV, the major accounting firms are international in structure; international trade in accounting (and related) services is a substantial reality. But the widespread local regulatory restrictions that these firms face force them into inefficient compromises that restrict the freer flow of personnel and information as well as restricting organizational forms and structures that would allow greater efficiency. The inevitable consequence is higher costs, poorer service to their clients, and reduced efficiency.

The following is a list of frequently cited examples of restrictions and restraints imposed by 
one or more countries that favor domestic incumbents and discriminate against non-citizen providers, thereby inhibiting freer trade and greater efficiency in accounting services: ${ }^{24}$

-- Nationality requirements with respect to who can offer local accounting services.

-- Residence or establishment requirements.

-- Restrictions on the international mobility of accounting personnel.

-- Restrictions as to the use of the brand names of firms, or requirements that only local names be used.

-- Restrictions on advertising or other promotional efforts; restrictions on price competition.

-- Quantitative limits on the provision of services.

-- Restrictions on the services that accounting firms can and cannot provide.

-- Restrictions on who can be an owner of an accounting firm; e.g., requirements that all or a specified number or fraction of the owners of an accounting firm be local citizens; be residents; be active in the business of the firm; be locally-licensed; be members of an approved professional organization.

-- Restrictions as to the legal form or structure that an accounting firm must have (e.g., prohibitions on a corporate form).

-- Discriminatory arrangements with respect to the licensing of foreign accountants, including applications, testing, assessments of educational qualifications, relevant experience.

-- Differential taxation treatment.

-- Restrictions on international payments for services.

${ }^{24}$ See, for example, OECD (1996, 1997), IFAC (1995), USITC (1996a, 1996b, 1997, 1998), Hegarty (1997), and WTO (1998). 
-- Restrictions on cross-border flows of information.

-- Inadequate protections for the intellectual property related to accounting services, such as computer software.

-- "Buy national" practices of governments with respect to their purchases of accounting services.

It is worth noting that even in instances where the restrictions appear to affect domestic incumbents and foreign entrants similarly (e.g., restrictions on advertising), the effect is likely to be differentially adverse to the foreign entrant, since the entrant may need advertising or other promotion to enter and expand in a market dominated by domestic incumbents.

In many instances it is the larger accounting networks that are prevented from expanding and strengthening their international presences. Since the cultures of these larger networks are those of relatively high accounting and auditing standards, an ironic consequence (for a professional service where a major rationale for local regulation is consumer protection and the maintenance of high quality) of these restrictions has surely been quality standards for accounting and auditing in many countries that are lower than they otherwise could be.

Similar compilations of restrictions have been available since at least the early $1980 \mathrm{~s}^{25}$ As the interest in trade in services has grown and as negotiations have become more substantive in the 1990s, the compilations have become more frequent as well. ${ }^{26}$ Comparisons of the lists from the 1980s with those of the 1990s show a striking similarity in the types and nature of the restrictions.

\footnotetext{
${ }^{25}$ See Macrae (1981) and Rossi (1986).

${ }^{26}$ See, for example, OECD (1996, 1997), IFAC (1995), USITC (1996a, 1996b, 1997, 1998), Hegarty (1997), and WTO (1998).
} 
Though simple comparisons by themselves cannot indicate the presence or absence of any progress in the removal of restrictions, there is a strong sense that progress has been only modest. Indeed, as was noted in Section II, it was the absence of immediate progress in reducing barriers that contributed to the International Federation of Accountants' disappointment with the WTO's adoption of the multilateral disciplines at the end of 1998.

There is thus considerable room for future negotiations to convert many countries' expressions of good intentions in removing restrictions into a freer flowing reality. 


\section{Differing Accounting Standards: How Important Is Harmonization?}

The differing accounting frameworks or standards that are in use in most countries are often described as part of the barriers to freer trade in accounting services. In reality, they are at most a modest barrier. Instead, these differing accounting standards have more importance for the operations of international capital markets and for the operations of international enterprises more generally.

Nevertheless, because the issues of differing accounting standards and potential harmonization of standards are frequently linked to discussions of liberalization of international trade in accounting services, ${ }^{27}$ and they are important in their own right, they deserve some discussion here. ${ }^{28}$

\section{A. Are differing accounting standards a barrier to liberalization?}

In principle, the differing accounting frameworks that are in force in different countries are a barrier to the liberalization of trade in accounting services. Differing standards place extra burdens on international firms and make the movement of personnel somewhat more costly. Incumbent domestic firms thereby gain a modest advantage vis-a-vis foreign-based firms. And differing accounting frameworks do appear as a barrier on many lists of impediments to freer trade.

But differing accounting frameworks have not been adopted or manipulated as a specific

\footnotetext{
${ }^{27}$ See, for example, Ascher (1999).

${ }^{28}$ Harmonization of accounting standards has received extensive discussion in the academic accounting literature; see, for example, Nobes (1996), Wyatt (1997), and Mueller (1997).
} 
effort to protect domestic incumbent accountants vis-a-vis entrants from abroad. Further, the international accounting firms face similar differential burdens with respect to differing local spoken languages and differing local legal systems. The international accounting firms readily adapt to those differing frameworks, and they have readily adapted to differing accounting standards. Differing accounting frameworks appear to be a modest barrier at most. If harmonization proves to be worthwhile, it will be for the reasons discussed below, and not as a major initiative to liberalize trade in accounting services.

B. The value from accounting harmonization -- and some cautions.

The real value from eliminating the differences in national accounting systems and harmonizing on a common system lies elsewhere -- in reducing international enterprises' accounting costs, in helping integrate international capital markets, and in serving as the guise whereby countries with deficient accounting frameworks are induced to improve their accounting standards. But harmonization also has drawbacks that warrant discussion.

1. Reducing accounting costs. To the extent that an enterprise operates in different jurisdictions and must prepare financial reports for the different jurisdictions according to differing accounting frameworks, its costs are higher than if it could use a single framework. Further, to the extent that the enterprise additionally uses a single framework for its own informational purposes, its costs are yet higher.

2. Integrating international capital markets. As the rapid technological improvements in telecommunications and data processing dramatically reduce the costs of transmitting and analyzing information, providers and users of capital around the globe are increasingly being brought into 
transactions with each other. To the extent that the borrowers/users employ differing accounting frameworks among themselves, the tasks of the lenders/investors in comparing and assessing risks and prospects are made more difficult; in the parlance of microeconomics, differing accounting frameworks increase the transactions costs of operating in international capital markets. Harmonization to a common standard can reduce those transactions costs and promote the smoother flow of capital across international boundaries. $^{29}$

3. Improving deficient standards. Where countries have deficient (poor quality) accounting frameworks -- as is often the case in developing countries -- the effort at international harmonization (which takes the developed world's standards as its general base) could serve as the means for raising the quality of the accounting frameworks in these countries. Arguably, a similar process has been at work with respect to the international harmonization of capital requirements for banks. $^{30}$

3. Some cautions. The case for harmonization to reduce the costs of capital is strongest where the accounting differences are arbitrary and serve no useful distinguishing purposes, or where harmonization is the guise for strengthening (e.g., increasing the transparency of) a country's weak accounting framework. But the differences may reflect adaptations to different characteristics of different economies: for example, whether an economy has had periodic bouts of severe inflation, which might call for revaluations of financial stocks and flows, or has experienced only modest

\footnotetext{
${ }^{29}$ See the discussion of harmonization in White (1996).

${ }^{30}$ See White (1996).
} 
inflation, which might call for the avoidance of the vagaries that could accompany revaluations. ${ }^{31}$ Further, there are serious conceptual/philosophical questions as to whether financial accounting should have a stewardship focus, which would call for an orientation toward historical costs, or a current-value focus.

Accordingly, harmonization is not a win-only proposition. Valuable adaptations to local conditions may be lost, and serious alternatives may be discarded. Further, with a single harmonized standard, the opportunities for localized experimentation and development of new alternatives are eliminated. Rigidities in accounting may be exacerbated.

In sum, harmonization carries potential costs as well as benefits. A weighing of both is warranted before judgments are made.

\section{Historical developments.}

The International Accounting Standards Committee (IASC), created in 1973, has been the main body that has focused on developing "international accounting standards" (IASs) that would be commonly adopted internationally and thus would be the harmonized standard. The creation of the International Organization of Securities Commissions (IOSCO) in 1986 and its interests in the development of IASs reinforced the mission of the IASC.

In 1995, the IOSCO and the IASC agreed that the latter should make a concerted effort to develop a set of core standards that the IOSCO could endorse and that its member countries could adopt for cross-border securities offerings and other foreign listings. Also the European Union was

\footnotetext{
${ }^{31}$ For discussions of these differential adaptations, see Pownall and Schipper (1999) and Gebhardt (2000).
} 
encouraging its member states to allow their companies to use IASs and to accept each other's companies' financial statements (on a mutual recognition basis) for listing on each other's securities exchanges.

The IASC completed its tasks at the end of 1998, and decisions by IOSCO and its constituent members are awaited. ${ }^{32}$ A crucial role will be played by the U.S. Securities and Exchange Commission (SEC). The SEC has historically resisted other countries' accounting standards, insisting that any non-U.S. company that wanted to have its securities publicly traded in the U.S. must restate its financial accounts to U.S. generally accepted accounting principles (GAAP). ${ }^{33}$ The U.S. Financial Accounting Standards Board (FASB) issued a lengthy report in late $1999^{34}$ that was quite critical of the IASC's proposed standards.

Despite vaguely encouraging statements of SEC officials, ${ }^{35}$ the basic message of the SEC in the past and of the recent FASB report is that other countries' standards, including the IASC's proposed standards, are not sufficiently rigorous to protect investors in the U.S. securities markets. Consequently, it seems quite likely that the SEC will eventually reject the IASC's efforts as unnecessarily weakening the investor protections that are currently embodied in U.S.GAAP.

The consequences of the SEC's decision are likely to be less substantial than the partisans in the debate over IASs have indicated. Officials of the New York Stock Exchange, and others, have

\footnotetext{
${ }^{32}$ For a recent commentary, see McGregor (1999).

33 The SEC has, however, since 1990 (through Rule 144A) permitted private offerings to institutional and sophisticated investors of the securities of non-U.S. companies without requiring restatements to U.S. GAAP.

${ }^{34}$ See Bloomer (1999).

${ }^{35}$ See, for example, Sutton (1997).
} 
advocated adopting the IASC standards, or something similar, so as to enhance the role of the U.S. exchanges in international securities markets. They see the SEC requirement of restatement to U.S.GAAP as substantially raising the costs of a U.S. securities listing for non-U.S. companies and thereby discouraging U.S. listings and the use of the U.S. securities exchanges. What seems to be forgotten in this discussion is that a U.S. listing also carries with it the obligations to abide by the entire panoply of federal securities laws, which are also seen as burdensome by non-U.S. companies. The elimination or modification of the U.S.GAAP requirement would not alter these other securities laws obligations and would thus likely lead to far fewer new listings than the advocates expect. 


\section{The Current Framework for Negotiations}

Despite the Seattle experience, the WTO will likely remain an important forum for continued negotiations with respect to international trade in services. Negotiations with respect to trade in accounting services should proceed ahead of many others, because of the advances that have already been made with respect multilateral disciplines and guidelines on mutual recognition agreements. It is worth reviewing the structure of the GATS and its amplifications, ${ }^{36}$ which will be the structure under which the negotiations will occur. ${ }^{37}$

\section{A. The GATS.}

The GATS, which came into effect on January 1, 1995, is an extensive document that applies to all WTO members (as of April 2000, there were 136 member countries) and is intended to cover a broad range of services and circumstances. The document contains general obligations by member countries and narrower obligations that apply only to member countries that commit or bind themselves to liberalized trade in specific services sectors.

${ }^{36}$ A comparison between the listing of the barriers to trade in accounting services found in Section V and the listing of the major liberalizing provisions of the GATS found in Section VII yields an apparent disconnect. The reasons for the discrepancy are threefold: First, not all countries are members of the GATS; second, as is discussed in the text below, not all members of the GATS have scheduled the accountancy sector for liberalization commitments; and third, the provisions of the GATS will not come into force until the conclusion of the round of negotiations that is beginning in 2000 .

${ }^{37}$ See also, for example, Altinger and Enders (1996) for a more extended discussion of the GATS provisions. 
With respect to accounting services, the most important general-obligation provisions of the GATS are as follows: $:^{38}$

-- Article II of the GATS establishes a general obligation for most favored nation (MFN) treatment. $^{39}$

-- Article III establishes a general obligation for transparency with respect to laws, regulations, administrative guidelines, and similar measures that are relevant to trade in services. The transparency should include opportunities for inquiry and notification of significant changes.

-- Article VI applies to domestic regulation and requires members to ensure that qualification requirements and procedures, technical standards and licensing requirements do not constitute unnecessary barriers to trade. Domestic regulatory requirements should be based on objective and transparent criteria, such as competence and the ability to supply the service; should be not more burdensome than necessary to ensure the quality of the service; and, with respect to licensing procedures, should not in themselves be a restriction on the supply of the service. Members must provide an objective and impartial means of reviewing and providing appropriate remedies for administrative decisions that affect in services.

- Article VII encourages mutual recognition of the qualifications of services providers. Member recognition of foreign qualifications should not constitute a means of discrimination among countries in standards or criteria. Multilateral processes are encouraged.

In addition to the general obligations, the most important specific obligations that apply

\footnotetext{
${ }^{38}$ In the descriptions that immediately follow, liberal use of the exact language of the GATS will be made.

${ }^{39}$ However, countries can specifically exempt a sector from MFN treatment.
} 
when a country has made specific commitments with respect to a specific services sector (in this case, accounting) are as follows: ${ }^{40}$

-- Article VI requires that measures of general application that affect trade in services should be administered in a reasonable, objective, and impartial fashion. In addition, members should provide adequate procedures for the mutual recognition of the competence of other members.

-- Article XVI applies to market access and prohibits specific limitations (e.g., quotas) on the number of suppliers; on the total value of service transactions or assets, including needs tests; on the total number of service operations or total quantity of service output; on the total number of people that may be employed; on the types of legal entity or joint venture through which a service can be supplied; and on the participation of foreign capital.

-- Article XVII requires "national treatment"; i.e., members should accord to foreign services and service suppliers treatment that is no less favorable than is applied to domestic services and suppliers. Specific treatment can be different, so long as the resultant conditions of competition do not favor domestic services or service suppliers.

\section{B. Providing More Detail}

Both the general and the for-the-committed-only GATS obligations are broadly worded. Detailed and specific negotiations are required to flesh out these broad provisions. In order to

${ }^{40}$ It is important to note that even when a member country decides to commit (bind) itself with respect to a specific services sector, it can nevertheless do so with restrictions that limit the application of the GATS provisions discussed below. A member can list restrictions for an individual country, or it can "horizontally" list restrictions that apply across a number of sectors. 
facilitate these negotiations as applied to the accountancy sector, the WTO's Council for Trade in Services has adopted two additional measures that were developed by its Working Party on Professional Services (WPPS). First, in May 1997 the Council adopted non-binding guidelines for mutual recognition agreements (MRAs) for the accountancy sector, which amplify the provisions of Article VII of the GATS. The guidelines provide an extensive framework that is intended to help members structure their MRAs in ways that make them transparent and accessible.

Second, in December 1998 the Council adopted "disciplines" (rules) on domestic regulation of the accountancy sector that amplify the provisions of Article VI. ${ }^{41}$ The disciplines provide greater detail as to transparency, licensing requirements and procedures, qualification requirements and procedures, and technical standards.

The disciplines implicitly recognize that regulation of accountancy is ubiquitous, but they require members to ensure that such regulation is not more trade-restrictive than is necessary to fulfill legitimate objectives, including protection of consumers, the quality of the service, professional competency, and the integrity of the profession. With respect to licensing, the disciplines urge alternatives to residency requirements (e.g., allowing the posting of security bonds to serve as an alternative method of ensuring accountability); acknowledge professional organization membership requirements but require reasonable terms of membership; require that the use of firm names not be restricted (except in fulfillment of a legitimate objective -- e.g., to avoid consumer confusion); and require that licensing procedures be transparent and not

\footnotetext{
${ }^{41}$ The disciplines specifically state that they are not meant to apply to measures that are covered under the commitment (scheduling) provisions of Articles XVI and XVII. It was this absence of application that was part of the reason for the IFAC's tepid endorsement of the disciplines. For a more extensive discussion of the disciplines and the negotiation processes, see Ascher (1999).
} 
unnecessarily burdensome.

With respect to qualifications, the disciplines require transparency and reasonable procedures as to examinations and other qualifications and a link between the qualifications and the activities for which the authorization is sought. Members are required to take account of qualifications (such as education, experience, and/or examinations) that have been acquired in other countries. They are encouraged to note the role that MRAs can play in facilitating the verification of qualifications or establishing their equivalency.

With respect to technical standards (i.e., accounting standards or frameworks themselves), the disciplines require that such standards be prepared, adopted, and applied only to fulfill legitimate objectives. ${ }^{42}$

Finally, as was noted in Section II, the disciplines will not come into force until the conclusion of the round of services negotiations that is starting in 2000; until that conclusion, the members cannot raise new barriers to trade in accountancy services.

\section{An Evaluation.}

It is tempting, and easy, to be pessimistic about the prospects for trade liberalization in services. In important respects, the GATS and its amplifications represent a gingerly, somewhat tentative approach to liberalized trade. It is riddled with exemptions: Member countries can simply decide which sectors they wish to commit to the obligations of Article XVI (market access), Article

42 As Ascher (1999) notes, the WPPS concluded that the harmonization of accounting frameworks was not a major goal for the disciplines, since the frameworks were primarily within the purview of the IOSCO and the IASC. 
XVII (national treatment), and parts of Article VI (domestic regulation); even for committed sectors, members can still list and maintain restrictions; and even a general obligation like MFN (Article II) can be avoided by a member for specific sectors. Further, the accountancy disciplines did not tackle Article XVI (market access) and XVII (national treatment) issues, such as residency and citizenship requirements and more rigorous requirements for foreign applicants than for domestic applicants.

In addition, despite going into effect in 1995, the general principles of the GATS (and the more specific details of the accountancy disciplines of 1998) will not actually have a positive impact in reducing barriers (though they will prevent the raising of new barriers) to trade in services until the conclusion of negotiations that are beginning in 2000. Given the experiences of past rounds of trade negotiations (and the experience of the recent Seattle disruptions), this conclusion might well occur only in the middle of the decade. Thus, real impact might be delayed for almost a decade after the inauguration of the GATS.

Despite this multitude of limitations, undue pessimism with respect to the future of trade liberalization in services is not warranted. ${ }^{43}$ The GATS is a new phenomenon with respect to multilateral agreements for services; and, as was discussed in Sections III and V of this paper, services are a highly sensitive area where domestic regulation is widespread and where domestic sovereignty issues remain potent. As the 50 years of experience with the GATT has indicated, completely free trade is an unrealistic goal, even over a five decade period. Progress is slow; the forces of protectionism are powerful. But the extent of progress in the GATT has been substantial,

\footnotetext{
${ }^{43}$ For a similar conclusion, see Altinger and Enders (1996).
} 
and the trend remains positive.

The same realistic perspective should be applied to any appraisal of the GATS. Progress will be slow, especially since services are a more sensitive area. The GATS does represent progress. The political imperative will be to keep the momentum going in the direction of freer trade. 


\section{The Road Ahead}

As of early 1999 there had been commitments by 67 members ${ }^{44}$ of the WTO with respect to accounting/auditing/bookkeeping services, of which 26 were developed countries ${ }^{45}$ and 41 represented developing and transition economies. ${ }^{46}$ Though these 67 countries represent only half of the WTO's membership, they do represent about $90 \%$ of international revenues for accounting services. $^{47}$ Detailed analyses of these commitments, however, indicate that many fall far short of a total embrace of free trade in accounting services. ${ }^{48}$ Also, as would be expected, the commitments by the developing and transition economies' governments are more limited than those of the developed country governments. ${ }^{49}$ And the extent of restrictions in commitments is greater for the "commercial presence" and "temporary presence" modes of delivery, which are the important modes for accounting, than for the remaining two modes. Still, the commitments represent a starting basis for negotiations and opportunities for further openings.

${ }^{44}$ Constituent countries of the European Union are counted separately.

${ }^{45}$ In addition to the EU, the developed countries included the U.S., Japan, Canada, Australia, New Zealand, Norway, and Switzerland.

46 See WTO (1998, 1999). Among the major developing countries that are members of the WTO but that did not make specific commitments with respect to accountancy were Egypt, India, Indonesia, Pakistan, and the Philippines.

${ }^{47}$ Ascher (1999).

48 See USITC (1996a, 1996b, 1997, 1998) and WTO (1998, 1999); see also Altinger and Enders (1996).

49 This pattern is consistent with the pattern of commitments across all services generally; see Altinger and Enders (1996). 
The basic principles encouraged by the GATS -- MFN treatment (Article II), transparency (Article III), restraining domestic regulation to legitimate ends (article VI), mutual recognition (Article VII), market access (Article XVI), and national treatment (Article XVII) -- should be strenuously pursued. Along these lines, the first goals should be the widespread elimination of the most egregious forms of regulatory protectionism of domestic accounting entities that clearly have little to do with consumer protection and that are fundamentally anti-consumer, since they raise costs and/or reduce the quality of accounting services. Included on this list should be the following items (along with the GATS articles that are likely to apply):

-- Restrictions on the use of foreign firms' brand names (Article VI and disciplines).

-- Restrictions on the mobility of personnel (Article XVI).

-- Discriminatory taxation (Article XVII).

-- Discriminatory licensing arrangements (Article VI and disciplines; Article XVI).

-- Quantitative limits on the provision of services (Article VI and disciplines; Article XVI).

-- Restrictions on legal structural forms (Article XVI).

-- Restrictions on advertising, promotion, and pricing (Article VI and Article XVI).

-- Buy national policies (Article XIII; Article XVI; Article XVII).

-- Nationality, residence, or establishment requirements (Articles VI and disciplines; Article XVI; Article XVII).

-- Ownership restrictions (Articles VI; Article XVI; Article XVII).

This is an ambitious agenda. Wherever possible, negotiators should focus on the general obligation articles (i.e., Articles II and III and parts of Article VI) rather than the for-the-committedonly articles (e.g., Articles XVI and XVII). 
If all or most of these restrictions can be eliminated among most of the WTO's 136 members, much will be achieved. Attention can then be turned to the tougher questions of mutual recognition of qualifications (Article VII) ${ }^{50}$ protection of intellectual property, and restrictions on payments (Article XII).

These negotiations are unlikely to be easy. The heavy hands of domestic regulation will surely be important inertial forces. But the Asian financial crises of 1997 should provide added power and urgency to the arguments favoring freer trade in accounting services, especially in developing and transition economies:

It is clear that poor accounting practices by local banks and other important local enterprises in a number of Asian countries were partially responsible for the problems that arose. Liberalized trade in accounting services would provide greater opportunities for entry and for greater local influence by the large international accounting firms. In turn, these large firms -- with their greater ability to mobilize expertise, their general culture of higher accounting standards, and their substantial international reputations at stake -- are likely to be stronger forces for more reliable accounting and auditing. ${ }^{51}$ Indeed, the World Bank apparently has informally asked the Big Five to

${ }^{50}$ Despite the presence of the guidelines on MRAs, progress has been slow in achieving actual MRAs (WTO 1998). This is not surprising, since the process of determining the equivalency of qualifications -- for the purpose of consumer protection -- is difficult indeed. Though this problem may not be quite so apparent for accounting, it is starkly apparent for physicians. Also, it is worth noting that even within the U.S., the 50 states (which are the local regulators of the accountancy profession) have had difficulties in achieving MRAs among themselves.

${ }^{51}$ This statement does not mean that the large international accounting firms are wholly free of the potential conflicts of interest that are always present when a company audit may reveal information that may displease incumbent management -- the party that has hired the auditor and that usually has the power to re-engage the auditor for the following year. The potential conflicts are even more serious when a "sister" management consulting arm of the auditing firm may also be 
avoid signing financial statements that, although prepared in accordance with local accounting standards, are below prevailing international standards. ${ }^{52}$ In an era of the increasing globalization of financial markets, this strengthening of the accounting/auditing function in many countries should be quite valuable in aiding their abilities to access those markets. ${ }^{53}$

engaged by the audited company. But the greater reputations of the large firms mean that they have more to lose from subsequent revelations of shoddy work, which in turn should make them less likely to be tempted to stray.

${ }^{52}$ See WTO (1998) and Muis (1999).

${ }^{53}$ See, for example, McKee and Garner (1992, 1996), Riahi-Belkaoui (1994), Saudagaran and Diga (1997), and McKee et al. (1998). 


\section{$\underline{\text { IX. Conclusion }}$}

Accounting is an essential infrastructural element of the business sector in any modern economy; it is crucial for finance. Efficiency in the way that accounting services are delivered can enhance the efficiency of the rest of the economy.

The large accounting firms are already international in scope and operation. But national regulatory restrictions hobble their ability to operate fluidly across national boundaries in ways that would best serve their clients. International trade in accounting services is substantially impaired.

The GATS negotiations that are beginning in 2000 hold the promise for important liberalizations of trade in accounting services. These negotiations should be pursued vigorously, with efforts to expand the countries involved, expand their commitments, and conclude the negotiations promptly. The gains from this vigorous pursuit will be substantial. 


\section{$\underline{\text { References }}$}

Ascher, Bernard, "Trade Disciplines for Regulation: Lessons from the Accountancy Sector," paper delivered at the Conference on (R)Evolution of Quality and Competency Assurance in the Global Marketplace, Santa Fe, N.M., June 2-4, 1999. Washington, D.C.: USTR, draft 7/28/99, mimeo.

Aharoni, Yair, "Ownerships, Networks, and Coalitions," in Yair Aharoni, ed., Coalitions and Competition: The Globalization of Professional Business Services. New York:

Routledge, 1993, pp. 121-142.

Altinger, Laura and Alice Enders, "The Scope and Depth of GATS Commitments," The World Economy, 19 (May 1996), pp. 307-332.

American Institute of Certified Public Accountants and National Association of State Boards of Accountancy, Digest of State Accountancy Laws and State Board Regulations (1998).

Bloomer, Carrie, ed., The IASC-U.S. Comparison Project: A Report on the Similarities and Differences between IASC Standards and U.S. GAAP, 2nd edn.. Norwalk, Conn.: Financial Accounting Standards Board, 1999

Doogar, Rajib and Robert F. Easley, "Concentration without Differentiation: A New Look at the Determination of Audit Market Concentration," Journal of Accounting \& Economics, 25 (June 1998), pp. 217-253.

Fox, Nancy Ruth and Lawrence J. White, "U.S. Ocean Shipping Policy: Going against the Tide," Annals of the American Academy of Political and Social Science, 553 (September 1997), pp. 7586.

Gebhardt, Gunther, "The Evolution of Global Standards of Accounting," in Robert E. Litan and Anthony M. Santomero, eds., Brookings-Wharton Papers on Financial Services 2000. Washington, D.C.: Brookings Institution, 2000 (forthcoming).

Goldberg, Lawrence G. and Lawrence J. White, "The Role of Banks in Transition Economies," in Alan Young, ed., Economies in Transition: Conception, Status, and Prospects, 2000 (forthcoming)

Hegarty, John, "Accounting for the Global Economy: Is National Regulation Doomed to Disappear?" Accounting Horizons, 11 (December 1997), pp. 75-90.

International Federation of Accountants, IFAC Questionnaire on Issues Related to International Trade in Accountancy Services: Summary of Responses. New York: July 1, 1995. 
International federation of Accountants, "IFAC Welcomes WTO's Rules for the Accountancy Sector -- But Urges Further Progress," press release, December 17, 1999.

Macrae, Edwin W., "Impediments to a Free International Market in Accounting and the Effects on International Accounting Firms," in John C. Burton, ed., The International World of Accounting: Challenges and Opportunities. Reston, Va.: Council of Arthur Young Professors, 1981, pp. 143-153.

Mann, Michael A., Laura L. Brokenbaugh, and Sylvia Bargas, "U.S. International Services: CrossBorder Trade in 1998 and Sales through Affiliates in 1997," Survey of Current Business, 79 (October 1999), pp. 48-95.

McGregor, Warren, "An Insider's View of the Current State and Future Direction of International Accounting Standard Setting," Accounting Horizons, 13 (June 1999), pp. 159-168.

McKee, David L. and Don E. Garner, Accounting Services, Growth, and Change in the Pacific Basin. Westport, Conn.: Quorum, 1996.

McKee, David L. and Don E. Garner, Accounting Services, the International Economy, and Third World Development. Westport, Conn.: Praeger, 1992.

McKee, David L., Don E. Garner, and Yosra AbuAmara McKee, Accounting Services and Growth in Small Economies: Evidence from the Caribbean Basin. Westport, Conn.: Quorum, 1998.

Mills, Patti A. and Joni J. Young, "From Contract to Speech: The Courts and CPA Licensing Laws, 1921-1996," Accounting, Organizations, and Society, 24 (April 1999), pp. 243262.

Most, Kenneth S., The Future of the Accounting Profession: A Global Perspective. Westport, Conn.: Quorum, 1993.

Mueller, Gerhard G., "Harmonization Efforts in the European Union," in Frederick D.S. Choi, ed., International Accounting and Finance Handbook, 2nd edn. New York: John Wiley \& Sons, 1997, pp. 11-1 - 11-34.

Muis, Jules W., "Global Accounting, Auditing and a Financial Architecture," prepared remarks at the SEC International Institute for Securities Market Development, April 12, 1999. Washington, D.C.: World Bank, mimeo.

Nobes, Christopher W., ed., International Harmonization of Accounting. Brookfield, Vt.: Elgar, 1996.

Organization for Economic Cooperation and Development, International Trade in Professional 
Services: Advancing Liberalization Through Regulatory Reform. Paris: OECD, 1997.

Organization for Economic Cooperation and Development, International Trade in Professional Services: Assessing Barriers and Encouraging Reform. Paris: OECD, 1996.

Peltzman, Sam, "Toward a More General Theory of Regulation," Journal of Law \& Economics, 19 (August 1976), 211-40.

Posner, Richard A., "Theories of Economic Regulation," Bell Journal of Economics and Management Science, 5 (Autumn 1974), pp. 335-358.

Pownall, Grace and Katherine Schipper, "Implications of Accounting Research for the SEC's Consideration of International Accounting Standards for U.S. Securities Offerings," Accounting Horizons, 13 (September 1999), pp. 259-280.

Riahi-Belkaoui, Ahmed, Accounting in the Developing Countries. Westport, Conn.: Quorum, 1994.

Rossi, F.A., "Government Impediments and Professional Constraints on the Operations of International Accounting Organizations," University of Chicago Legal Forum (1986), pp. $135-168$.

Saudagaran, Shahrokh M. and Joselito G. Diga, "Financial Reporting in Emerging Capital Markets: Characteristics and Policy Issues," Accounting Horizons, 11 (June 1997), pp. 41-64.

Stigler, George, J., "The Theory of Regulation," Bell Journal of Economics and Management Science, 2 (Spring 1971), pp. 3-21.

Sutton, Michael H., "Financial Reporting in U.S. Capital Markets: International Dimensions," Accounting Horizons, 11 (June 1997), pp. 96-102.

U.S. International Trade Commission, General Agreement on Trade in Services: Examination of the Schedules of Commitments Submitted by Eastern Europe, the European Free Trade Association, and Turkey. Publication 3127, September 1998.

U.S. International Trade Commission, General Agreement on Trade in Services (GATS): Examination of Asia/Pacific Trading Partners'Schedules of Commitments. Publication 3053, August 1997.

U.S. International Trade Commission, General Agreement on Trade in Services (GATS): Examination of Major Trading Partners' Schedules of Commitments. Publication 2940, January 1996a. 
U.S. International Trade Commission, General Agreement on Trade in Services (GATS): Examination of South American Trading Partners' Schedules of Commitments. Publication 3007, December 1996b.

Weinstein, Grace W., The Bottom Line: Inside Accounting Today. New York: New American Library, 1987.

White, Lawrence J., International Trade in Ocean Shipping Services: The United States and the World. Cambridge, Mass.: Ballinger, 1988.

White, Lawrence J., "Competition versus Harmonization: An Overview of International Regulation of Financial Services," in Claude Barfield, ed., International Trade in Financial Services. Washington: American Enterprise Institute, 1996, pp. 5-48.

White, Lawrence J., "Financial Services in the United States: The Next Decade," Business Economics, 33 (October 1998), pp. 27-33.

World Trade Organization, Council for Trade in Services, "Accountancy Services," December 4, 1998.

World Trade Organization, Council for Trade in Services, "Structure of Commitments for Modes 1, 2, and 3," March 3, 1999.

Wyatt, Arthur R., "International Accounting Standards and Organizations: Quo Vadis?" in Frederick D.S. Choi, ed., International Accounting and Finance Handbook, 2nd edn. New York: John Wiley \& Sons, 1997, pp. 10-1 - 10-22. 
Table 1: Percentages of Domestic Revenues Attributable to Major Lines of Activity, Largest U.S. Accounting Firms, 1998

$\begin{array}{cc}\text { Largest } & \text { Largest } \\ 100 \text { Firms } & \underline{5 \text { Firms }}\end{array}$

Accounting/Auditing $30 \div 30 \%$

$\operatorname{Tax}$

$23 \quad 19$

Management consulting

47

$\underline{51}$

Total

$100 \% 100 \%$

Source: Accounting Today, "The Top 100 Firms," Special Supplement (March 15 - April 4, 1999), p. 5. 
Table 2: The Numbers of Countries in Which the Largest Twenty International Accounting Firms/Networks Have Operations, $1998 / 1999$

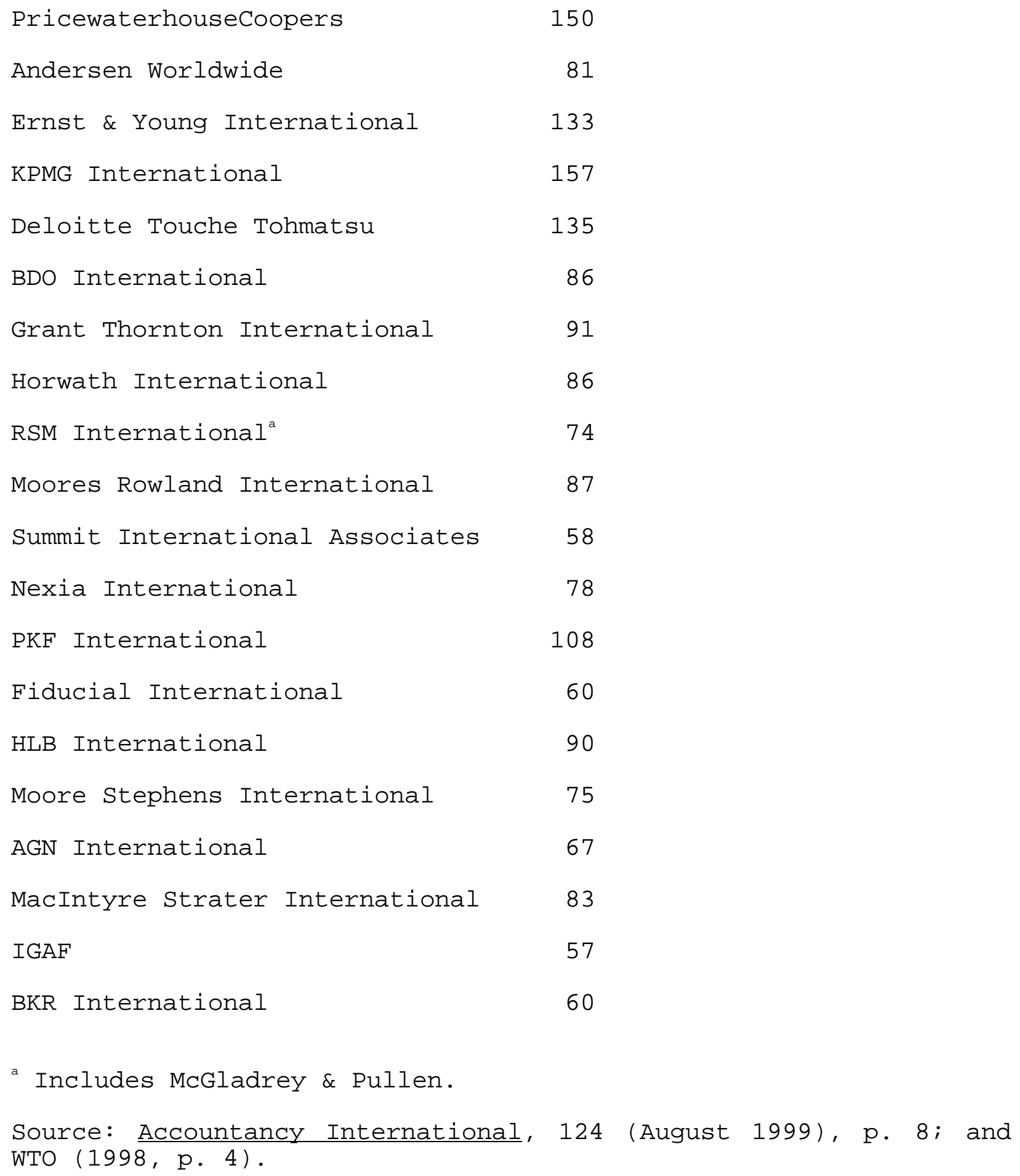


Table 3: Sizes of the Forty Largest International Accounting Firms/Networks, 1998/1999

\begin{tabular}{|c|c|c|c|c|}
\hline $\begin{array}{r}\mathrm{R} \epsilon \\
(\$ \mathrm{bj} \\
\end{array}$ & $\begin{array}{l}\text { evenue } \\
\text { illions) }\end{array}$ & $\begin{array}{l}\text { No. of } \\
\text { Offices }\end{array}$ & $\begin{array}{c}\text { No. of } \\
\text { Partners }\end{array}$ & $\begin{array}{c}\text { No. of } \\
\text { Prof. Staff }\end{array}$ \\
\hline PricewaterhouseCoopers & $\$ 15.3$ & 1,183 & 10,000 & 146,000 \\
\hline Andersen Worldwide & 13.9 & 412 & 2,788 & 93,916 \\
\hline Ernst \& Young & 10.9 & 675 & 6,200 & 58,700 \\
\hline KPMG & 10.4 & 825 & 6,790 & 64,510 \\
\hline Deloitte Touche Tohmatsu & 9.0 & 725 & 5,608 & 60,790 \\
\hline Total for Big Five: & $5 \overline{9.5}$ & $\overline{3,820}$ & $3 \overline{1,386}$ & $2 \overline{92,516}$ \\
\hline BDO International & 1.6 & 510 & 1,732 & 12,176 \\
\hline Grant Thornton International & 1.5 & 584 & 2,335 & 12,725 \\
\hline Horwath International & 1.2 & 369 & 1,790 & 11,280 \\
\hline RSM International ${ }^{a}$ & 1.2 & 524 & 1,864 & 10,623 \\
\hline Moores Rowland International & 1.1 & 603 & 1,884 & 10,717 \\
\hline Total for next five: $\quad 6.6$ & 2,5 & 9, & 605 & $57,52 \overline{1}$ \\
\hline Total for next 30 : & 11.2 & 6,964 & 19,169 & 114,924 \\
\hline Grand total for all 40: & 77.3 & 13,374 & 60,160 & 464,961 \\
\hline Big Five as a of of grand total: & $77 \%$ & $29 \%$ & $52 \%$ & $63 \%$ \\
\hline \multicolumn{5}{|l|}{ a Includes McGladrey \& Pullen. } \\
\hline
\end{tabular}

